\title{
Simulated Flow of Groundwater and Brine from a Flooded Salt Mine in Livingston County, New York, and Effects of Remedial Pumping on an Overlying Aquifer
}

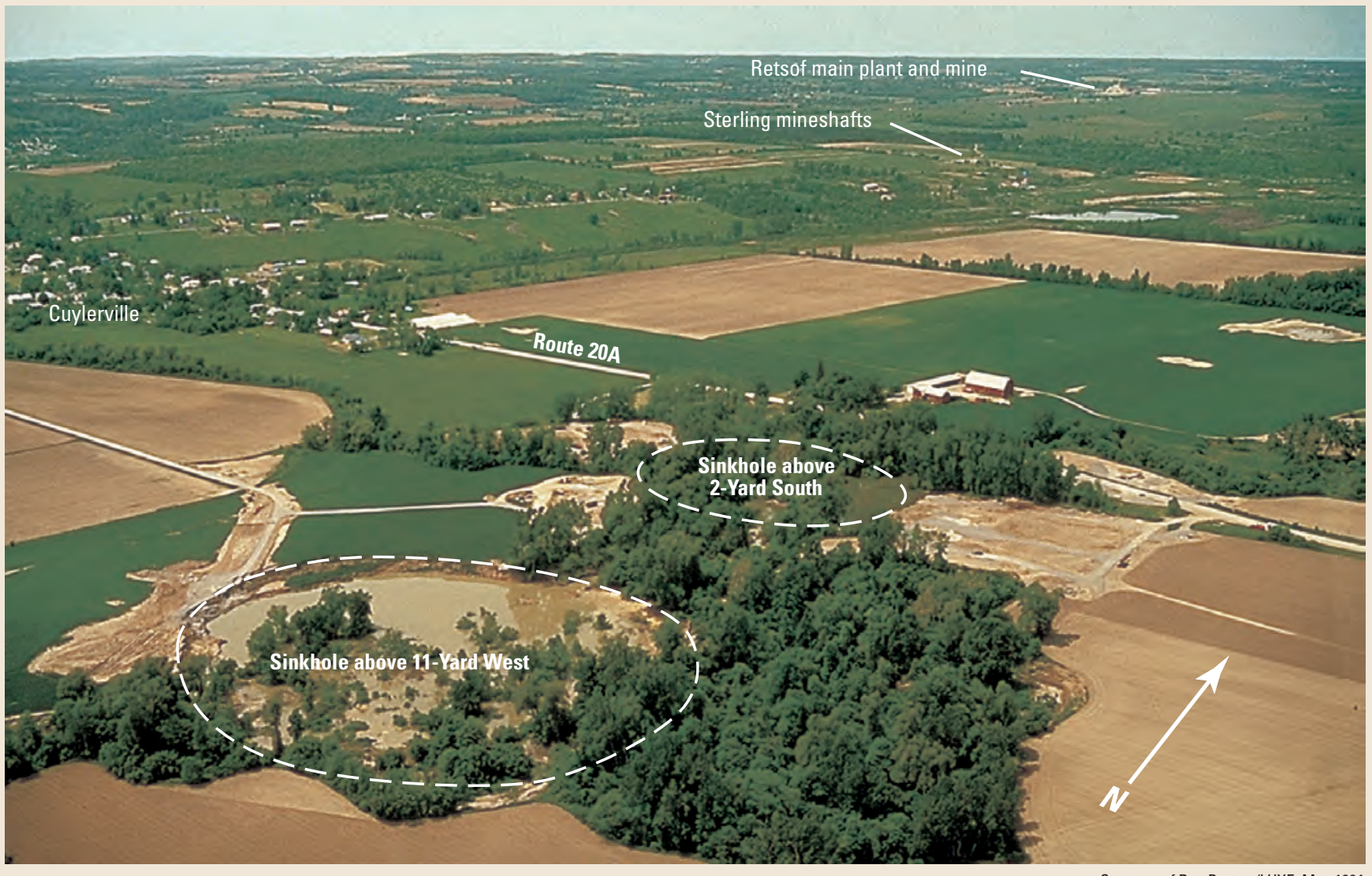

This northwest aerial view shows sinkholes above room 11-Yard West (left foreground) and room 2-Yard South (right center, partially obscured by trees) of the Retsof salt mine. The Retsof main plant is located about 4 miles northwest of the sinkholes.

Simulations of the movement of brine from a flooded salt mine near Geneseo, New York into an overlying aquifer indicate the following effects, if remedial pumping were discontinued:

- Saline water from bedrock would flow upward toward an overlying aquifer through rubble chimneys in bedrock that hydraulically connect the flooded salt mine to the aquifer. Halite brine from the mine would eventually reach the aquifer along the same path.

Dense saline water that reaches the aquifer through the rubble chimneys would migrate southward along the sloping bedrock surface to its lowest point south of the mine.

- A pool of saline water would form in this depression and extend northward and southward as the flow continues; however, the high relative density of the saline water would probably prevent it from rising into other overlying aquifers.

- The fate of mine water (brine) that enters bedrock fracture zones that intersect the rubble chimneys is uncertain. Some might emerge updip to the north, where a limestone subcrop area intersects the bedrock surface. The traveltime, however, cannot be calculated from available information. 


\section{Introduction}

Two ceiling collapses in the Retsof salt mine near Geneseo in upstate New York (fig. 1) in spring 1994 resulted in the upward propagation of two columns of rubble through 600 feet of overlying shale and carbonate bedrock (fig. 2). This upward propagation formed a hydraulic connection between the lower confined aquifer (LCA) and the mine and allowed water from the aquifer and bedrock fracture zones that intersected the rubble columns to flow into the mine at a rate of 18,000 gallons per minute (gal/min) (fig. 3, steps 1-2). All salt mining ceased in September 1995, and the mine was completely flooded by January 1996 (figs. 1B; fig. 3, step 3).

The flow of water from the lower confined aquifer into the mine caused widespread drawdowns, and water levels in the

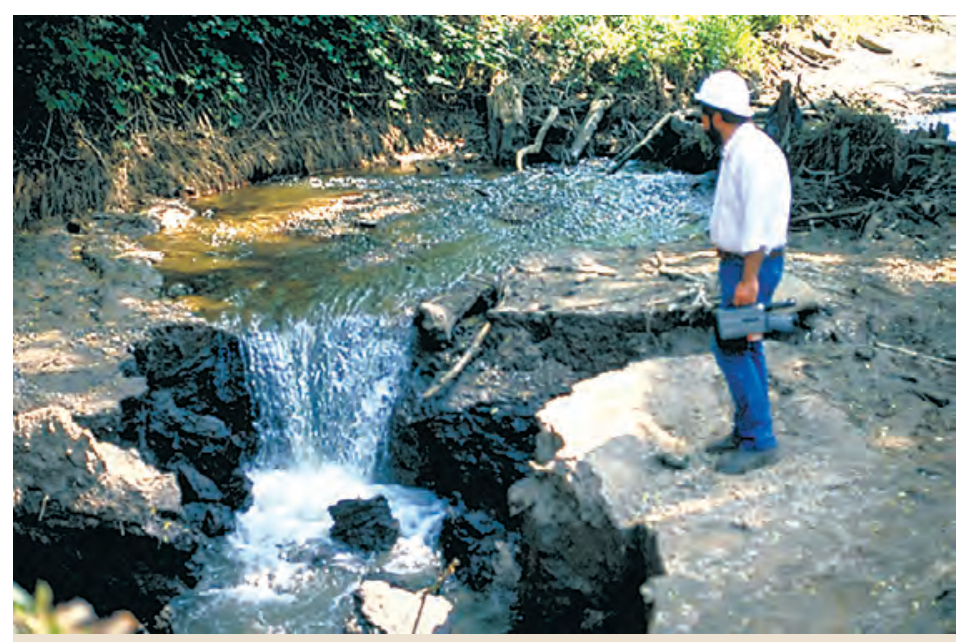

Photograph by Richard Young, Geological Sciences, State University of New York Geneseo, May 1994

In April and May 1994, sinkholes formed when rubble chimneys extended upward from the Retsof salt mine to land surface (about 1,100 feet). The formation of the sinkholes lowered the streambed of Beards Creek (shown above), a tributary of the nearby Genesee River, and water from the creek flooded the sinkholes. Eventually, both sinkholes measured 200 feet in diameter (cover photo).

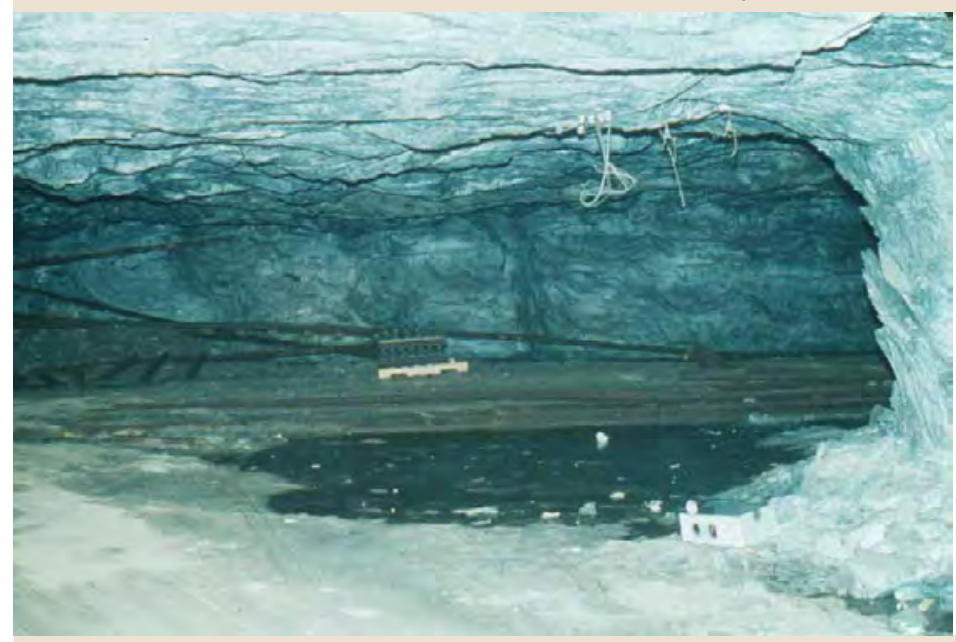

Photograph by William Kelly, New York State Geological Survey, June 1995

Picture shows rising water in the Retsof salt mine in June 1995 , following the collapse of two ceiling areas in the mine near Cuylerville, New York, on March 12, 1994. A pump out was attempted and abandoned. Mining ceased in September 1995, and the mine was flooded by January 1996. aquifer declined by as much as 400 feet near the collapse area and by more than 50 feet at wells 7 miles to the north and south. Within 3 to 4 weeks of the collapses, water levels in about a dozen domestic and industrial wells had declined severely, and some wells went dry. Water levels in at least 58 wells in the lower and middle confined aquifers were affected by mine flooding. Groundwater in the upper unconfined aquifer and surface water in streams were unaffected by water-level drawdown, but channels of the Genesee River and Beards Creek (fig. 1) were altered by land subsidence related to the mine collapse.

Water levels recovered from 1996 through 2006 (fig. 3, step 4), but the mine is now filled with about 16 billion gallons of saturated halite brine. The weight of the overlying rock and sediment is expected to cause the salt beds to deform and fill the mine cavity during the next several hundred years; this in turn could displace as much as 80 percent of the brine and cause it to move upward through the rubble chimneys, rendering the LCA unusable as a source of water supply. Saline water was detected in the LCA in 2002 but was found to be derived primarily from fractures in the limestone and shale units between the mine and the LCA, rather than from the mine.

In September 2006, the mine company began a brinemitigation project that entailed pumping five wells finished in limestone and shale units within the collapse areas to alter the flow gradient and thereby prevent further movement of brine and saline water into the LCA (fig. 3, step 5). The pumped brine was routed to an onsite desalination plant. At the same time, the U.S. Geological Survey (USGS) began a study in cooperation with the New York State Office of the Attorney General to construct numerical models to analyze the groundwater chemistry and delineate the directions of flow. Specific objectives of the study were to:

" Assess the sources of salinity within the collapse area and identify the factors that control the movement and mixing of freshwater, saline waters from fracture zones, and brine;

»Evaluate the likelihood that the pumping will induce anhydrite dissolution and lead to continued land subsidence;

» Construct variable-density groundwater flow models to predict the effect of remedial pumping on salinity within the LCA;

¿Evaluate the effectiveness of remedial pumping in preventing the movement of saline water into the LCA; and

»Predict the extent of brine migration 8 years after a hypothetical shutdown of all pumping in 2008.

This report (1) summarizes the hydrogeologic setting and effects of mine flooding, (2) describes the geochemical and variable-density model simulations and their principal results, (3) discusses the implications of (a) continued pumping and desalination to protect the LCA and (b) a full shutdown of pumping after 2008, and (4) suggests further research that could lead to refinement of model predictions. Additional information may be found in Yager and others (2001 and 2009). These reports can be accessed at http://pubs.usgs.gov/pp/pp1611/ and http://pubs.usgs.gov/pp/pp1767/, respectively. A summary of simulation results can be accessed at http://ny.water.usgs.gov/ projects/Coram/seawat/seawat.html. 


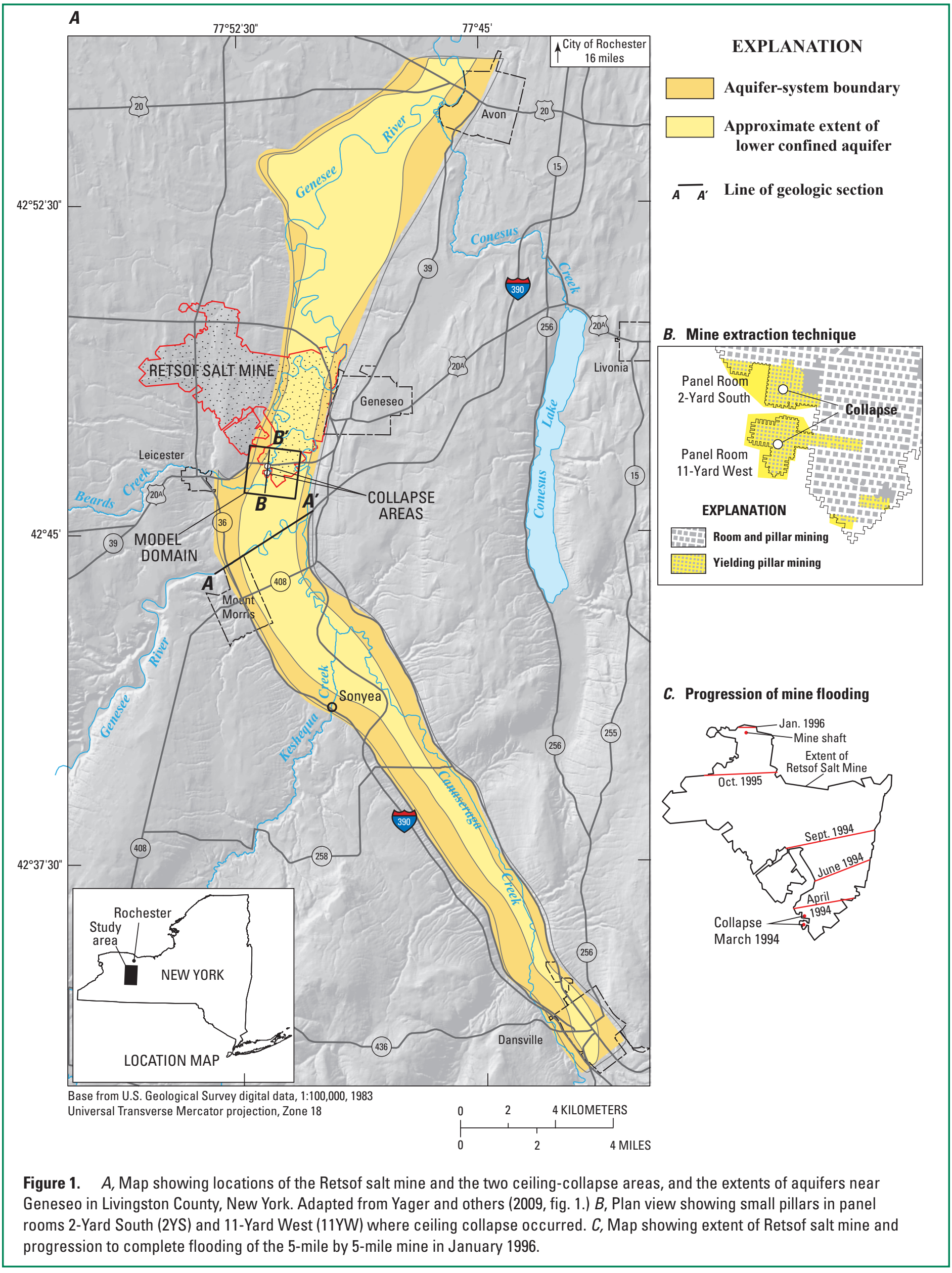



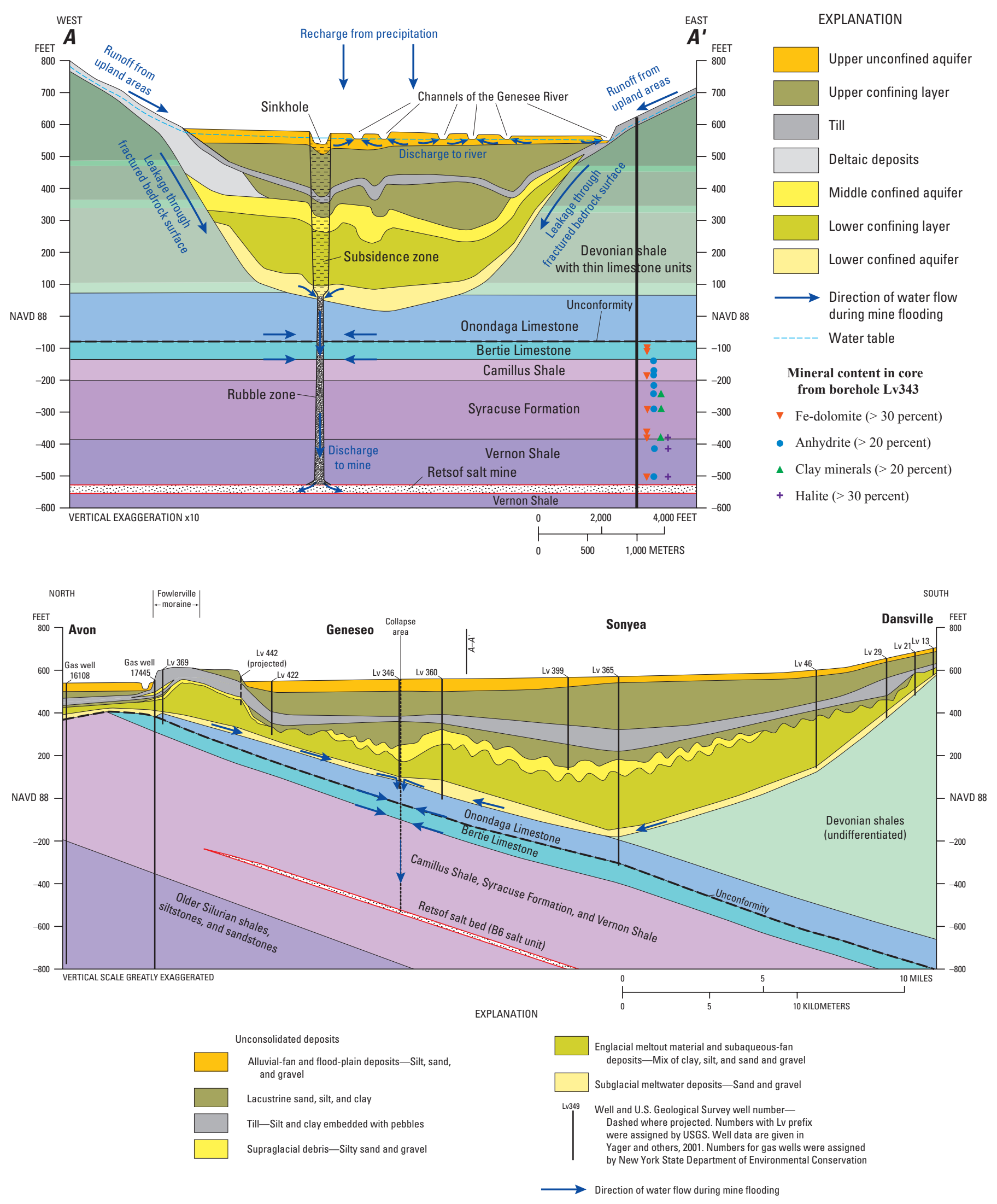

Figure 2. The upper stratigraphic cross-section $A-A^{\prime}$ shows one rubble chimney above the collapsed ceiling and the directions of groundwater flow into the Retsof salt mine, Livingston County, New York. The map view of the location of cross section $A-A^{\prime}$ is shown in figure 1 (from Yager and others, 2009, fig. 2). The lower cross section shows a view from north to south under the valley from Avon to Dansville, New York (see fig. 1), describing the unconsolidated deposits and direction of water flow in the lower confined aquifer during mine flooding. 


\section{Effects of Mine Flooding}

The flooded salt mine lies beneath a glacially scoured bedrock valley that contains the Genesee River in western New York (fig. 1). The mined salt bed is within Silurian shale overlain by nearly 600 feet of Devonian shale and limestone units that underlie a 500 -foot-thick glacial aquifer system containing an upper unconfined aquifer, a middle confined aquifer, and a lower confined aquifer (LCA). These aquifers are separated by thick confining layers (fig. 2).

Deformation of the overlying bedrock layers after the collapse resulted in land-surface subsidence that ranged from 15 feet over some parts of the mine to more than 70 feet above the rubble chimneys. As much as 0.8 feet of subsidence occur south of the mined area as a result of dewatering and compaction of fine-grained sediment in the confining layers of the glacial aquifer system. Two sinkholes that appeared over the rubble chimneys in April and May of 1994 each measured 200 feet in diameter and deepened as surficial sediment subsided into the sinkholes. The subsidence also damaged nearby structures, including a State highway bridge. Dissolution of salt pillars within the flooded mine increased the rate of mine-cavity closure and resulted in continued land subsidence that ranged from 1 to 16 feet over several parts of the mine (subsidence survey map shown on page 9).

Borehole geophysical surveys and drilling in the limestone units in April 1994 and March 2004 indicated that water in the bedrock units above the mine was initially flowing toward the rubble chimneys through two main horizontal fracture zones, and that the collapses had caused increased fracturing within these zones. These zones are designated the $\mathrm{O} / \mathrm{B}$ fracture zone between the Onondaga and Bertie Limestones and the $\mathrm{B} / \mathrm{C}$ fracture zone between the Bertie Limestone and the Camillus Shale (fig. 4). A less extensive Syr fracture zone is also present in the upper part of the Syracuse Formation.

Groundwater levels recovered and the hydrostatic pressure within the mine increased, thereby slowing the rate of land subsidence to less than 0.8 inches per year by 2006 . After the mine was flooded, saturated halite brine was displaced from the mine by the weight of the overlying material. The only outlet for displaced brine is upward through the rubble chimneys, although some brine could be diverted laterally into the bedrock fracture zones above the mine (fig. 4).

\section{Modeling Studies}

The chemistry of groundwater in the collapse area reflects the hydraulic and chemical processes that have occurred since mine flooding began in 1994. Geochemical models were developed to assess the sources of salinity (the flooded mine and the fracture zones within the overlying bedrock units) and to predict whether groundwater-quality changes induced by pumping would lead to mineral dissolution and additional land subsidence. Variable-density flow models were developed to (1) calculate the rates and directions of groundwater flow, (2) assess the effectiveness of mitigation pumping (from 2006 through 2008) in preventing migration of brine into the LCA and (3) predict the lateral extent of potential brine migration within the LCA if the pumping were terminated.

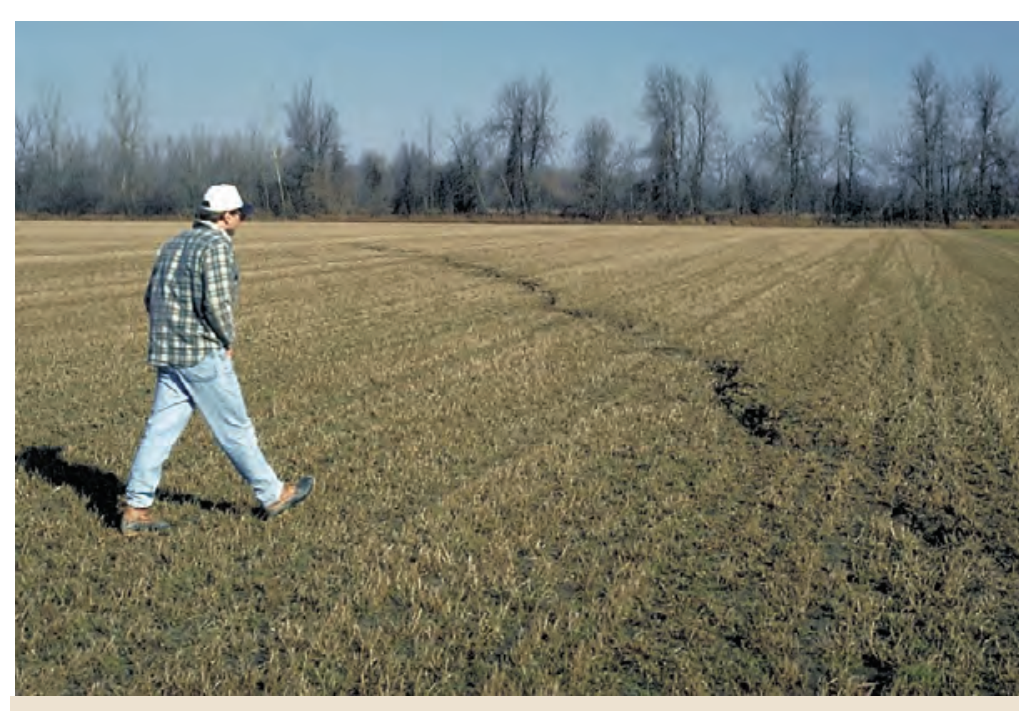

Photograph by Richard Young, Geological Sciences, State University of New York Geneseo, March 1995

An Earth fissure ruptures a field above the western edge of the mine, northwest of 2-Yard South sinkhole. The field surrounding the fissure had subsided almost 1 foot.

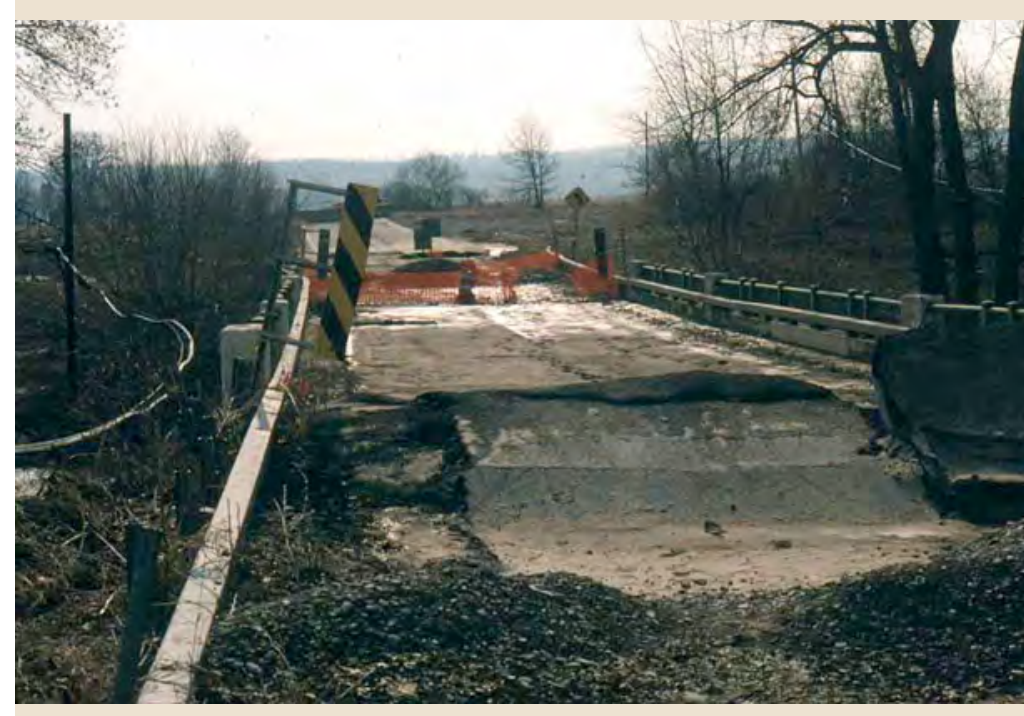

Photograph by William Kelly, New York State Geological Survey, April 1996

U.S. Route 20A bridge and utilities in April 1996 showing effects of surface subsidence.

\section{Geochemical Models}

Geochemical models for seven water samples in the collapse area were developed through PHREEQC (Parkhurst and Appelo, 1999) to analyze the variation in chemical composition of water in the collapse area and identify the mixing proportions of waters from three sources - halite brine from the flooded mine, saline water from the overlying bedrock units, and freshwater from the LCA. The models also were used to identify reactions between water and rock that explain the observed water chemistry in the collapse area. Additional geochemical models were used to assess the potential for mineral dissolution and land subsidence caused by the mixing of saline water and brine in the collapse area as induced by brine-mitigation pumping. 


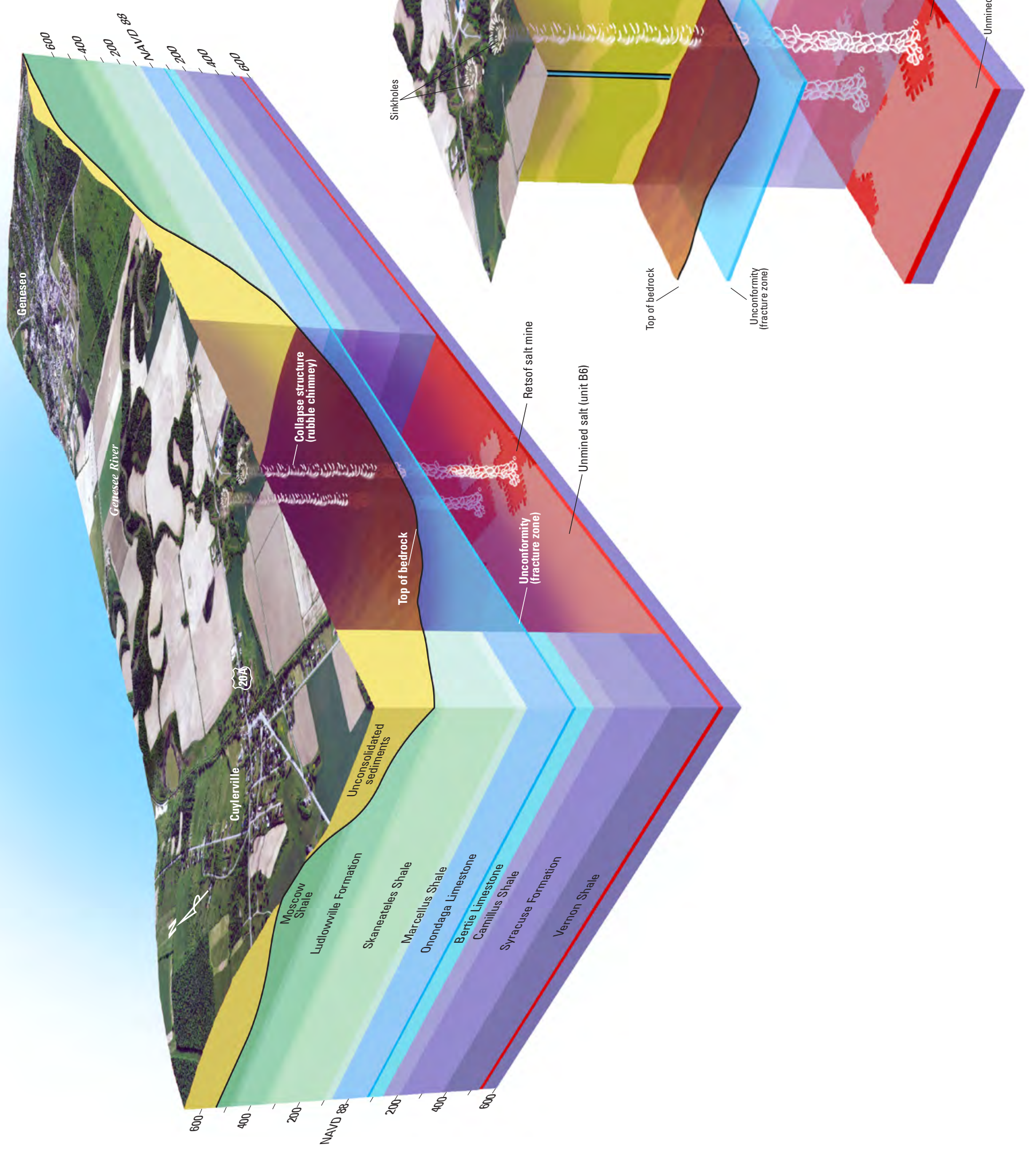




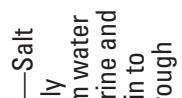

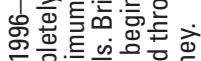

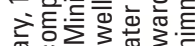

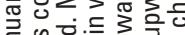

穴.

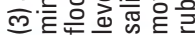

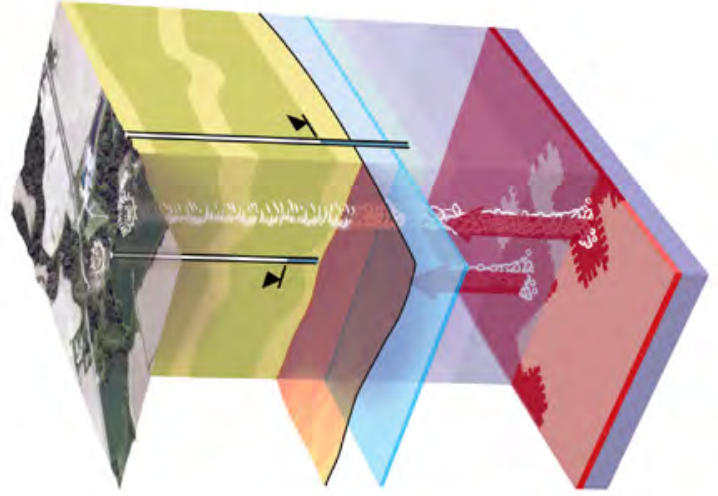

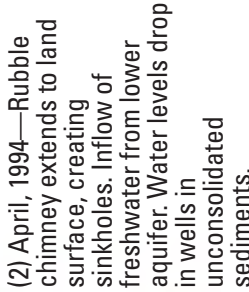

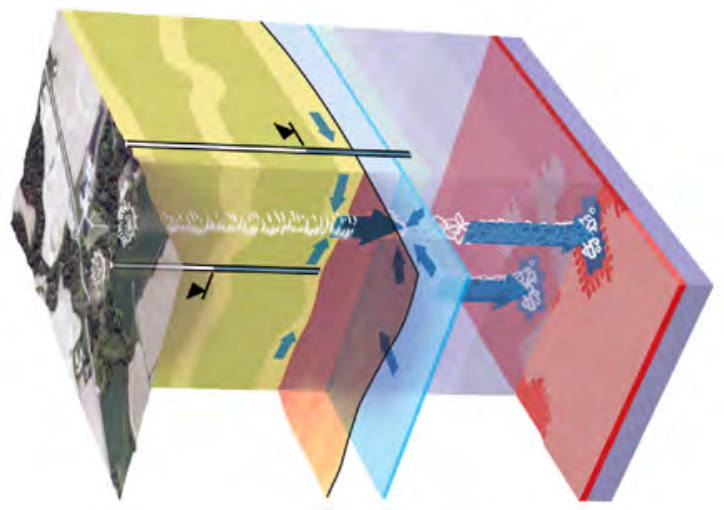

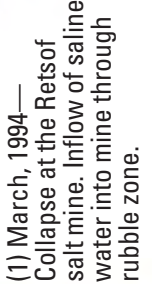

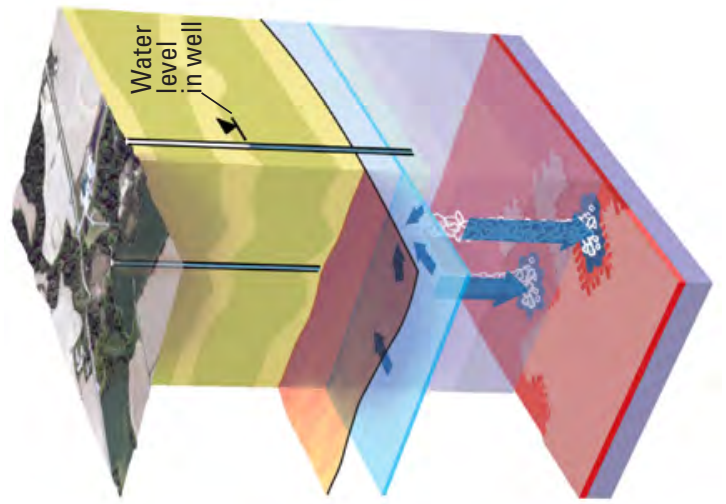

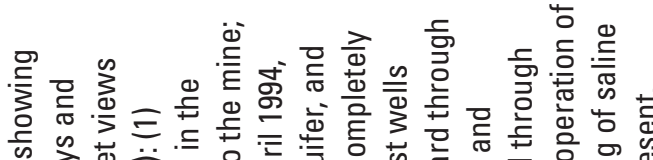
w d

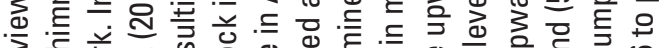

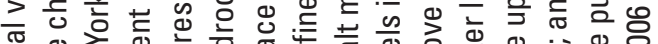
ত

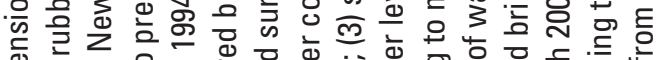
d

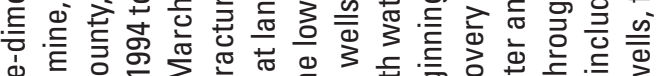

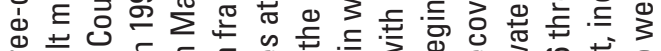

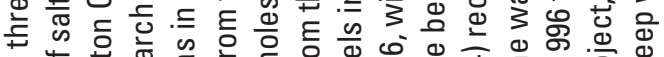
凹 芯芯高 ญ ब. ๗.)

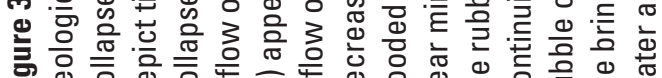
호웡
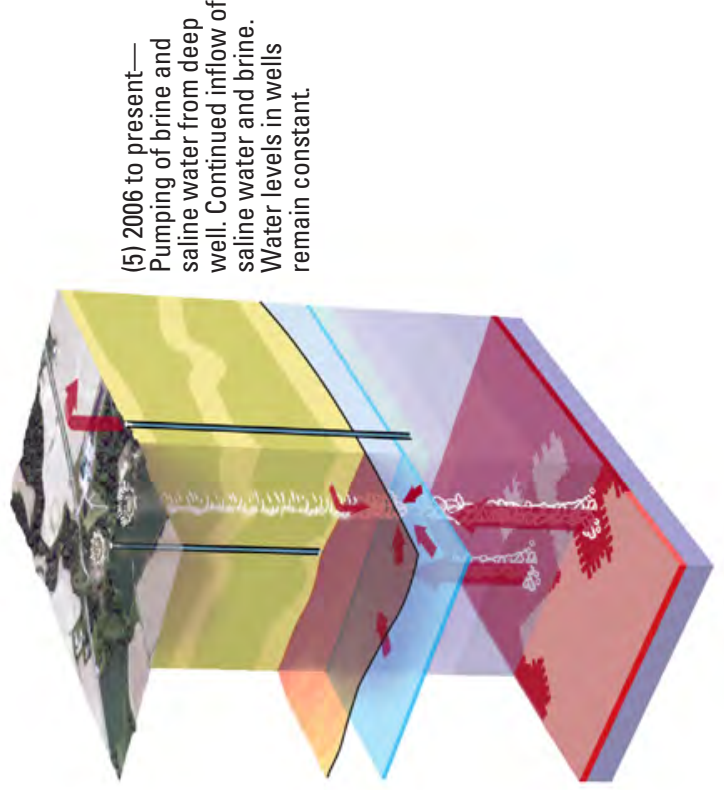

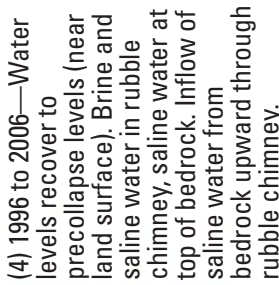

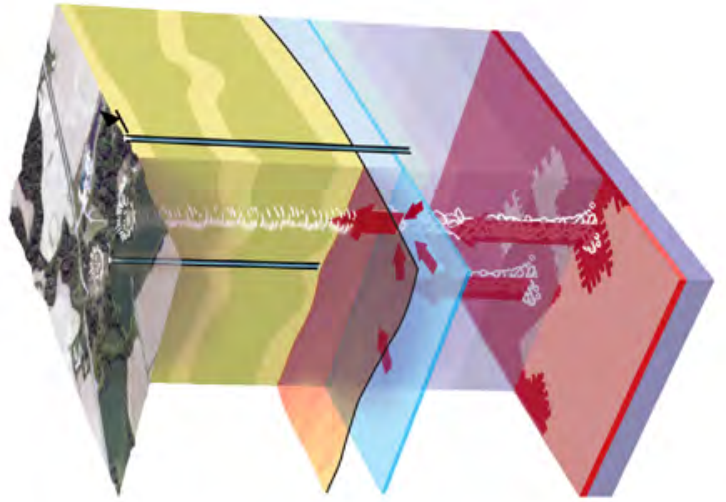



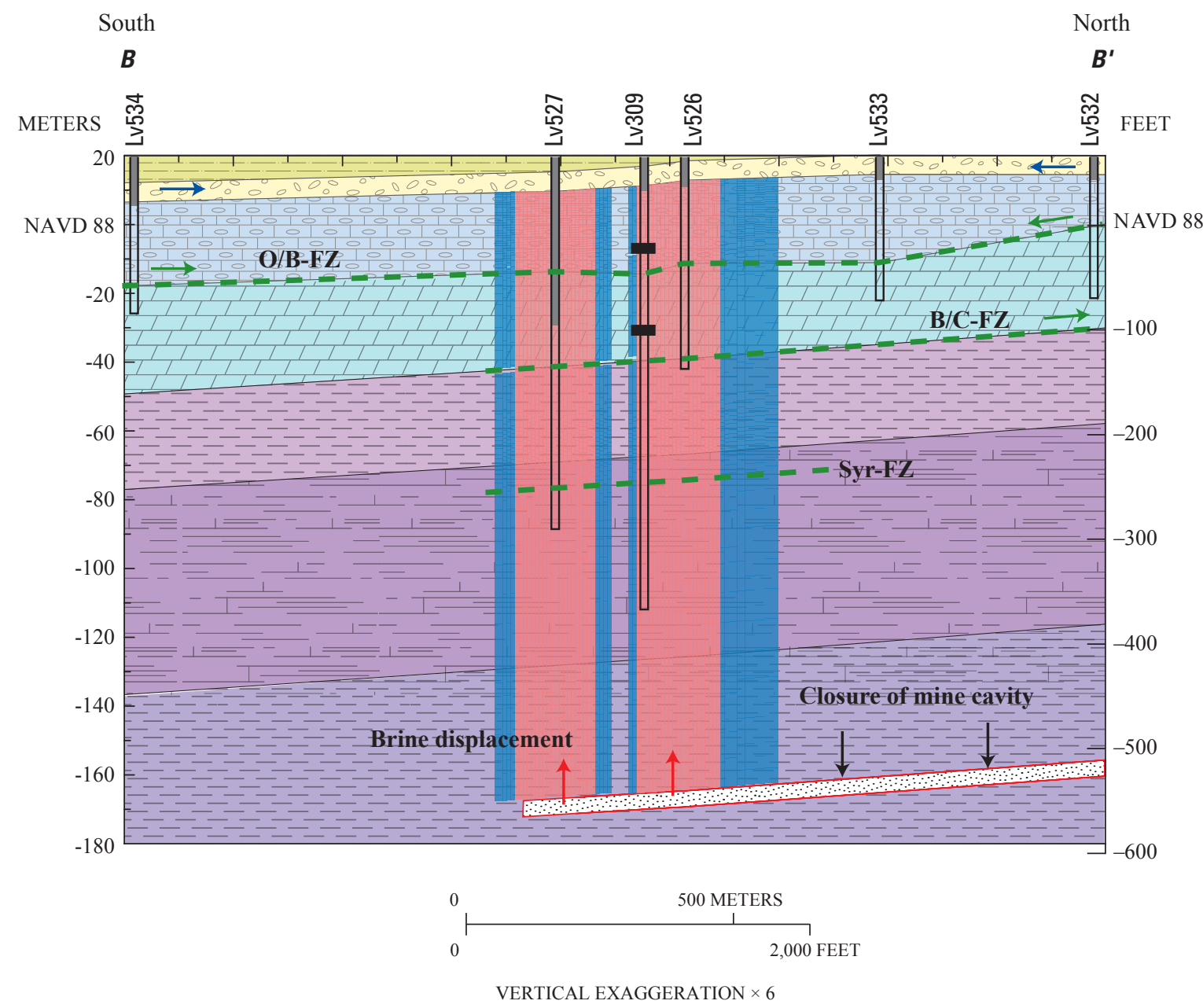

EXPLANATION

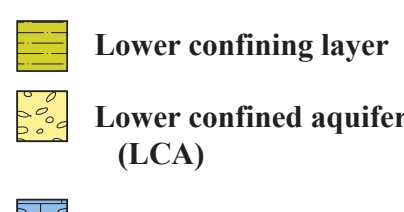

Onondaga Limestone

\section{Bertie Limestone}

Camillus Shale

Syracuse Formation

Vernon Shale

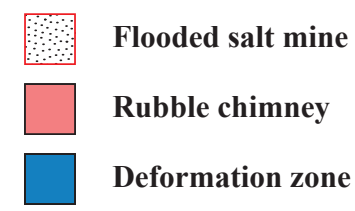

O/B-FZ Fracture zone and label

Monitoring well and number-
Cased interval shown in gray;
packer denoted by bold line

\section{Direction of flow}

Freshwater in LCA

Saline water in bedrock

Halite brine in mine and rubble chimneys

Figure 4. Stratigraphic cross-section B-B' showing rubble chimneys, the deformation zone in the collapse area above the flooded salt mine, and the direction of groundwater flow during water-level recovery, January 1996 through August 2006. Water flows toward the collapse area from the lower confined aquifer and the fracture zone (FZ) between the Onondaga and Bertie (O/B) Limestones. Brine from the mine is displaced upward into the chimneys by closure of the mine cavity. Location is shown in figure 1. From Yager and others, 2009, fig. 7. B/C-FZ, fracture zone between Bertie Limestone and Camillus Shale; NAVD 88, North American Vertical Datum of 1988. 
The results of the simulations indicated that the halite brine in the flooded mine is a mixture of aquifer water (81 percent), bedrock water (16 percent), and bromide-rich brine ( 3 percent) assumed to have formed following deposition of the salt during the Silurian Period. The halite brine from the mine cavity has become diluted with bedrock water as it flows upward through the rubble chimneys, whereas the saline water above the $\mathrm{O} / \mathrm{B}$ fracture zone is a mixture of saline bedrock water and aquifer water - an indication that brine from the flooded mine had not reached the LCA in 2006. The geochemical models indicated that land subsidence in the collapse area through anhydrite dissolution would not occur under prepumping (2005) conditions, and that subsidence through dissolution could occur but would be unlikely if pumping were kept at a lower rate than the upward flow of halite brine from the mine.

\section{Groundwater-Flow Models}

Analytical and numerical models were used to simulate the movement of aquifer water, bedrock water, and halite brine within the rubble chimneys and the surrounding deformation zones during the 10.7-year period of water-level recovery that followed the period of mine flooding (January 1996 through August 2006). Several one- and three-dimensional (1D and 3D) models were constructed through SEAWAT (Langevin and others, 2007), which simulates flow and solute transport.

The 1D models were used to simulate upward flow of brine to the LCA through a single rubble chimney to (1) obtain an estimate of the rate of upward brine migration and the longitudinal dispersivity of the rubble material and (2) indicate the number of model layers needed for the 3D simulations, which were designed to predict the movement of the transition zone between saline water and brine during the 10.7-year waterlevel-recovery period.

The 3D models simulated flow through both rubble chimneys and the surrounding deformation zone and represented the mixing of brine with bedrock water where fracture zones intersected the rubble chimneys. These models were used later to simulate the movement of aquifer water, bedrock water, and mine water in response to mitigation pumping from the collapse area that began in September 2006.

The 3-D models, which represented 1.8-square-mile areas surrounding the rubble chimneys, were each divided into 75 rows and 52 columns, with cell dimensions ranging from 33 feet to 980 feet (fig. 5). The final model had 159 layers and 238,558 active cells. The layers represent the regional bedrock dip from north to south, parallel to the flooded salt mine, with layer spacings that ranged from $13 \mathrm{ft}$ in the bottom half of the domain to $2 \mathrm{ft}$ in the upper half.

Two nearly identical 3D models (models A and B) were constructed to assess the hypothesis that salinity in the upper part of the profile is derived from the inflow of bedrock water from the limestone units, as indicated by the geochemical models, rather than from brine from the mine. Model A represented only fracture zone $\mathrm{O} / \mathrm{B}$, whereas model $\mathrm{B}$ represented three fracture zones: $\mathrm{O} / \mathrm{B}, \mathrm{B} / \mathrm{C}$, and Syr, as indicated by the observed salinity profile. The thickness and elevation of the fracture zones were interpolated from well borings and borehole geophysical logs. Simulations by the two models gave similar results, but differed slightly in the predicted composition of waters in the collapse area and in the values of some estimated model parameters.

A 1-day steady-state simulation with constant heads in the LCA and the flooded mine provided an initial head distribution for the transient-state simulation of the 10.7-year water-level recovery. The initial conditions were as follows: the mine was filled with brine; the LCA, the rubble chimneys, and the deformation zone were filled with freshwater; and the bedrock fracture zones were filled with saline water. The initial concentration of halite (halite saturation) of water in the rubble chimneys and deformation zone was specified as zero, and a constant saturation of 100 percent was specified for the bottom model layer (flooded mine). Constant heads were specified for each year during the 10.7-year recovery period according to those measured in the LCA. Injection of brine at 100-percent saturation was applied at the bottom model layer to represent brine being displaced from the flooded mine. The brinedisplacement rates were estimated through model calibration and were decreased from $110 \mathrm{gal} / \mathrm{min}$ at the beginning of the simulation to $25 \mathrm{gal} / \mathrm{min}$ at the end. These rates were consistent with the mean rate that was estimated through subsidence surveys during 1996-2001.

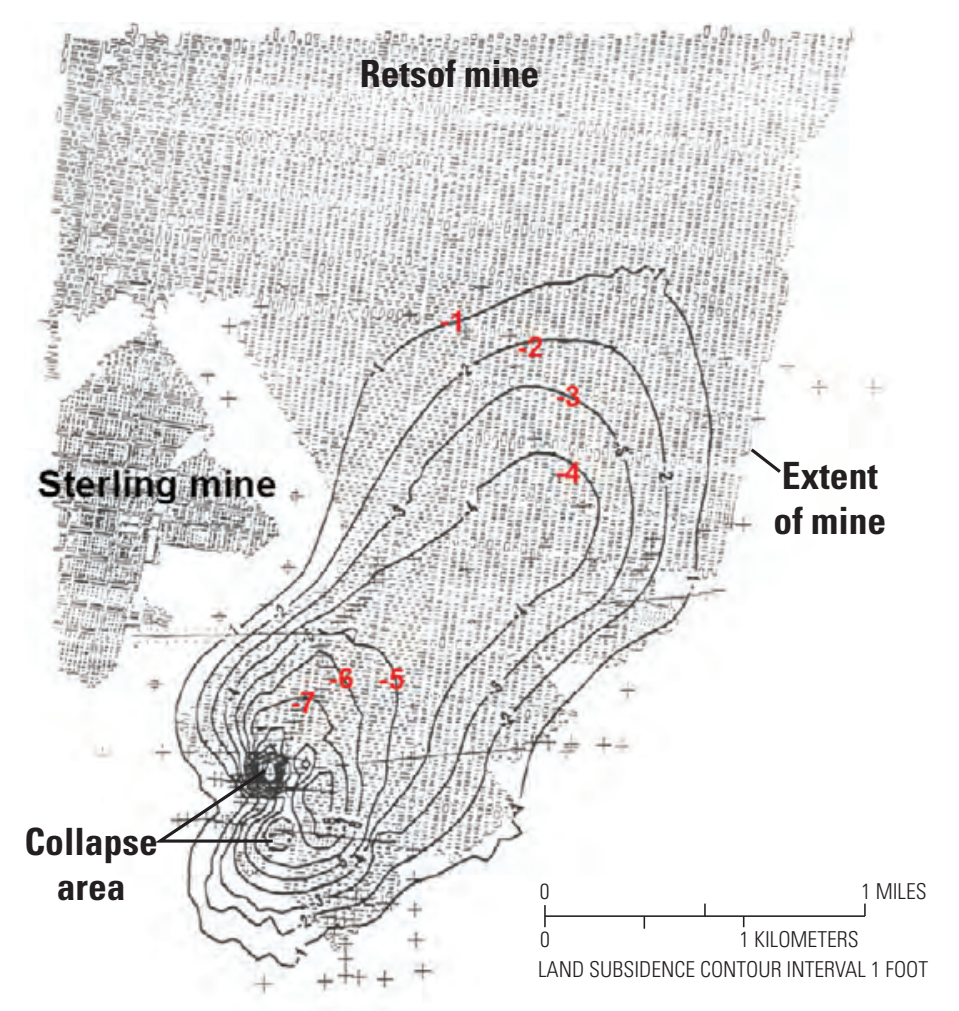

Modified from William M. Kelly, New York State Geological Survey, 2000

Land subsidence near the Retsof mine collapse area, in feet, from April 1995 to July 1996. Dissolution of salt pillars within the flooded mine increased the rate of mine-cavity closure and resulted in continued land subsidence that ranged from 1 to 16 feet over several parts of the mine. After the mine was flooded, saturated halite brine was displaced from the mine by the weight of the overlying material continuing to close the mine cavity. The only outlet for displaced brine is upward through the rubble chimneys, although some brine could be diverted laterally into the bedrock fracture zones above the mine (fig. 4). 

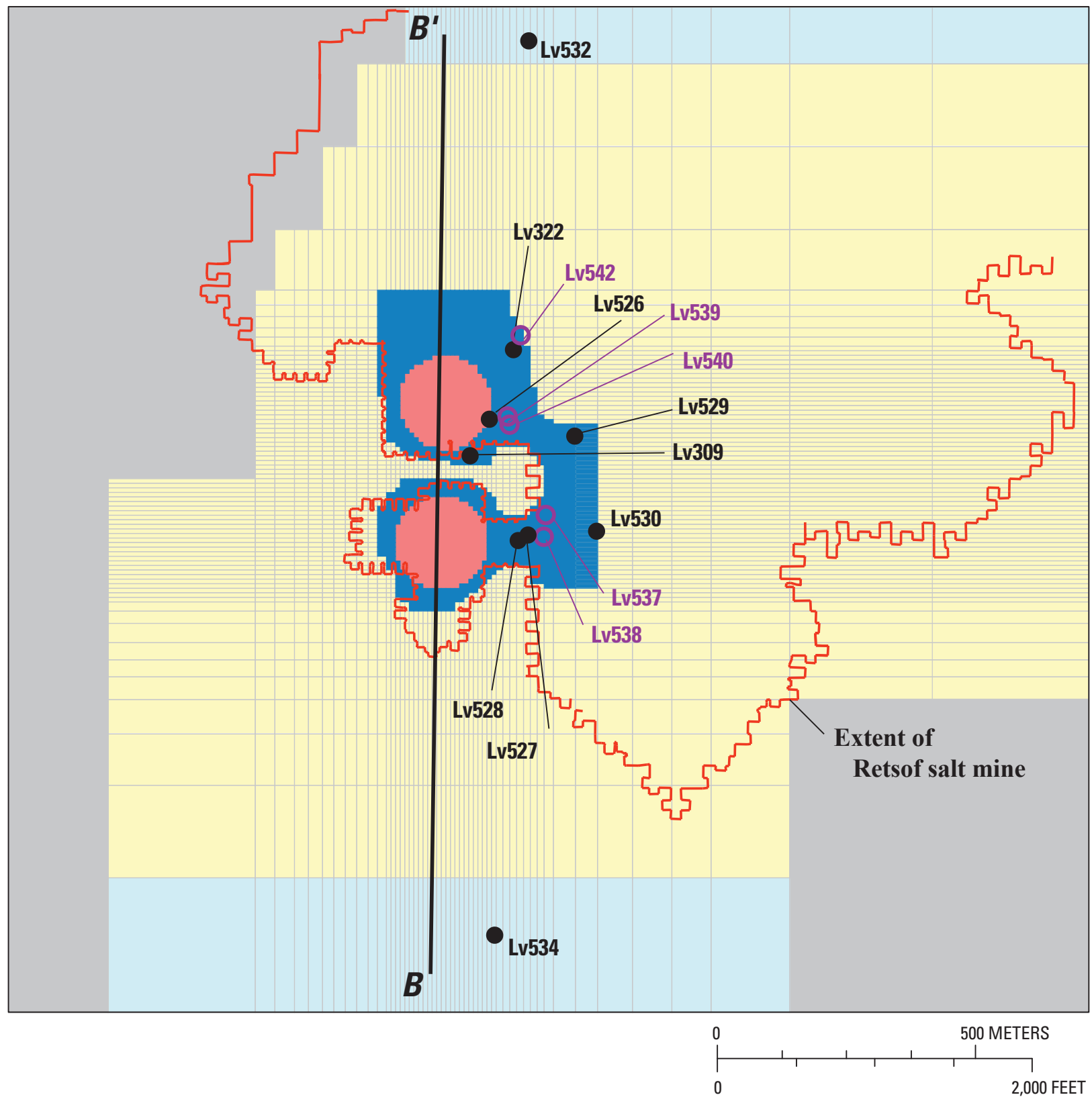

EXPLANATION

Lower confined aquifer, model layers 1 to 6

Inactive cell

Constant-head boundary, model layer 1
Rubble chimney, model layers 7 to 158

Deformation zone, model layers 7 to 158

$\bar{B} B^{\prime}$ Line of geologic section

Figure 5. Three-dimensional model domain with the extent of the salt mine and the locations of the stratigraphic crosssection B-B', the lower confined aquifer, the rubble chimneys, the deformation zone, and pumped and monitoring wells. From Yager and others, 2009, fig.16. 


\section{Model Calibration}

Both 3D models were calibrated through trial and error to match measured values of halite saturation in time-series plots and a salinity profile based on measurements made in September 2006. The models were intended to illustrate processes that control solute transport rather than to provide calibrated representations of the flow system. Values for hydraulic conductivity, percent porosity, and longitudinal dispersivity were specified for the LCA, the rubble chimneys, the deformation zone, and the three fracture zones. The models were most sensitive to rubble-chimney porosity, which determined the velocity of brine migration and the depth referenced to the North American Vertical Datum of 1988 (NAVD 88), of the transition zone between brine and saline water at the end of the 10.7-year simulation. Different porosity values were estimated for model A (10 percent) and model B (6 percent) to match the salinity profile. The mean inflow rates of groundwater into the collapse area from the $\mathrm{O} / \mathrm{B}$ fracture zone during the 10.7-year recovery period also differed (30 gal/min and $16 \mathrm{gal} / \mathrm{min}$ for models $\mathrm{A}$ and $\mathrm{B}$, respectively.

\section{Simulation Results}

Time-series plots and block diagrams were generated to depict (1) the progression of halite saturation; (2) changes in directions of groundwater flow and in proportions of mine water, bedrock water, and aquifer water at selected elevations; and (3) flow directions in and around the rubble chimneys and fracture zones as closure of the mine cavity forced mine water upward into the rubble chimneys and the fracture zones during 1996-2006 (fig. 6). Model B predicted a lower rate of salinewater inflow from the $\mathrm{O} / \mathrm{B}$ fracture zone than model $\mathrm{A}$ and indicated that mixing of waters from the other two fracture zones transported mine water higher in the water column than in model A. Both models indicated lateral diversion of brine into the $\mathrm{B} / \mathrm{C}$ fracture zone. Model B also indicated possible intrusion of mine water into the LCA. Although the geochemical simulation results do not support this interpretation, it could be valid if parts of the aquifer that were not sampled contained mine water.

Neither model A nor model B indicated that saline water had migrated laterally beyond the collapse area within the LCA. The origin of salinity in the upper part of the collapse area in model A (only one fracture zone) is consistent with results from the geochemical models, whereas the origin of salinity in model B (three fracture zones) indicates movement of mine water into all three fracture zones and is consistent with original predictions from the 1995 geotechnical studies (John T. Boyd Company, 1995) and borehole flow-meter surveys. Whether model A or model B more accurately represents conditions in the collapse area is unknown because the lateral extents of the fracture zones beyond the collapse area are not well delineated and because the boundary conditions specified for the mine and fracture zones are uncertain. As a result of these and other uncertainties, both models may not accurately represent flow and transport in the collapse area. The results, however, provide a description of the major processes and groundwater sources that contributed to the migration of brine and saline waternamely, the advection and dispersion of brine through the rubble chimneys and deformation zones - and the mixing of brine with saline water from fracture zones.
Simulated Effects of Mitigation Pumping During 2006-11

Models A and B were used to predict the changes in water levels and halite saturation that could be caused by the simulated pumping of the five brine-mitigation wells from September 2006 through August 2011 (fig. 5). Simulated results were compared with changes in water levels and halite saturation induced by pumping during 2006-08 and with the total mass of halite produced by the desalination plant. Both models simulated the movement of mine water, bedrock water, and aquifer water, and also the composition of water produced by each of the pumped wells.

The mitigation-pumping simulations by both models indicated that the current rate of pumping ( $25 \mathrm{gal} / \mathrm{min})$ will cause halite saturation in the collapse area to decrease and also will alter the directions of groundwater flow; this in turn will halt the upward migration of brine and saline water toward the LCA. The 5-year simulations indicated that the rate of brine displacement from the flooded mine is currently (2009) $25 \mathrm{gal} / \mathrm{min}$ or less and that as much as $5 \mathrm{gal} / \mathrm{min}$ is possibly being diverted laterally into the $\mathrm{B} / \mathrm{C}$ fracture zone.

Results of simulations with model B (three fracture zones) matched the halite saturation of the influent to the desalination plant, the amount of halite produced, and the observed decline in saturation through time better than model A (one fracture zone). Both sets of simulations reflected some of the actual conditions in the collapse area, but only simulations by model B indicated that more than one fracture zone affects the migration of saline water and mine water in the collapse area. The actual amount of mixing and rate of flow from the fracture zones, however, could be less than indicated by model B.

A sensitivity analysis with both models identified the parameters to which the simulation results were most sensitive. The results indicated that the principal controls on saturation and water levels were the rates of brine displacement from the mine and the pumping rate, and that the simulated rate of brine displacement could be slower than the actual rate because the simulated declines in saturation were smaller than those observed at most wells from September 2006 through February 2008.

\section{Implications for Future Mitigation Efforts}

The simulations of water-level recovery (1996-2006) indicate that saline water has probably not moved laterally beyond the collapse area within the LCA. The simulations of pumping (2006-08) indicate that pumping has halted the upward migration of brine and saline water and that salinity within the upper parts of the rubble chimneys and deformation zones will decrease over the next few years if the current rates of pumping ( $25 \mathrm{gal} / \mathrm{min})$ are maintained.

\section{Effects of Permanent Shutdown}

Additional 10-year simulations were conducted to predict changes in halite saturation within the $\mathrm{O} / \mathrm{B}$ fracture zone and the LCA if the brine-mitigation project had been halted in September 2008 after 2 years of pumping. Results of the simulations of a permanent shutdown with model A indicated that, in the absence of pumping, saturated brine would rise nearly to the O/B fracture zone in 3 years by September 2011 and extend laterally throughout the $\mathrm{O} / \mathrm{B}$ fracture zone within the 
A. January 1998
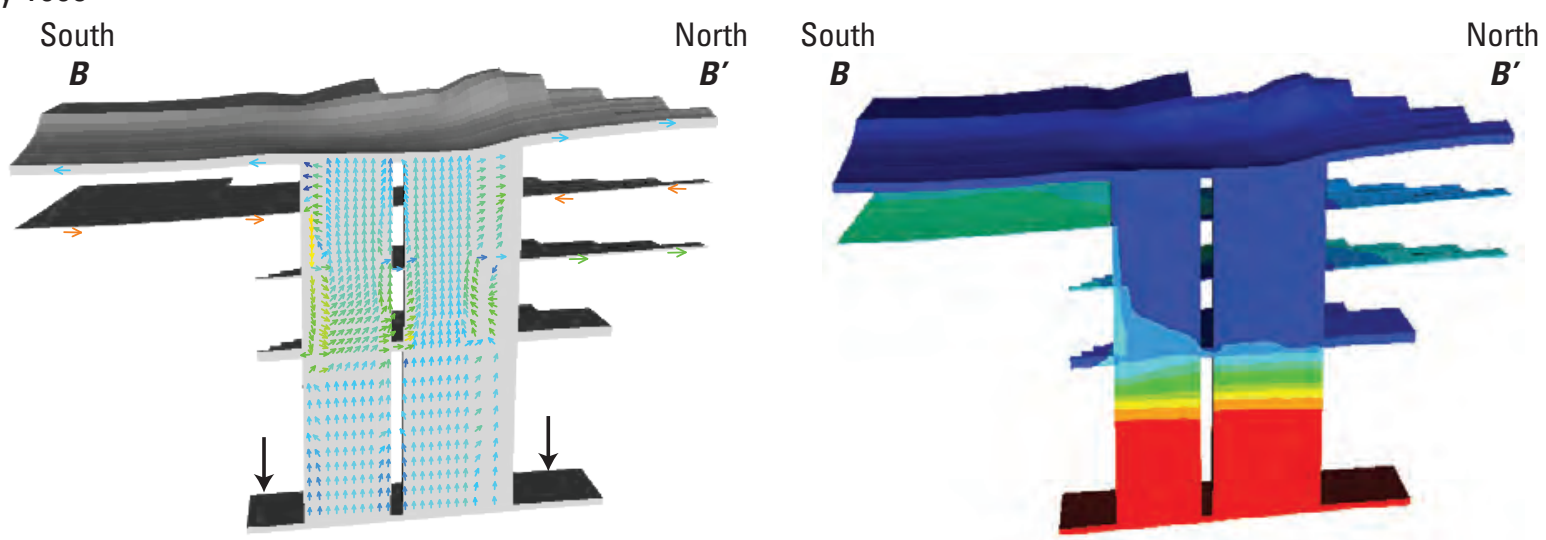

B. September 2006
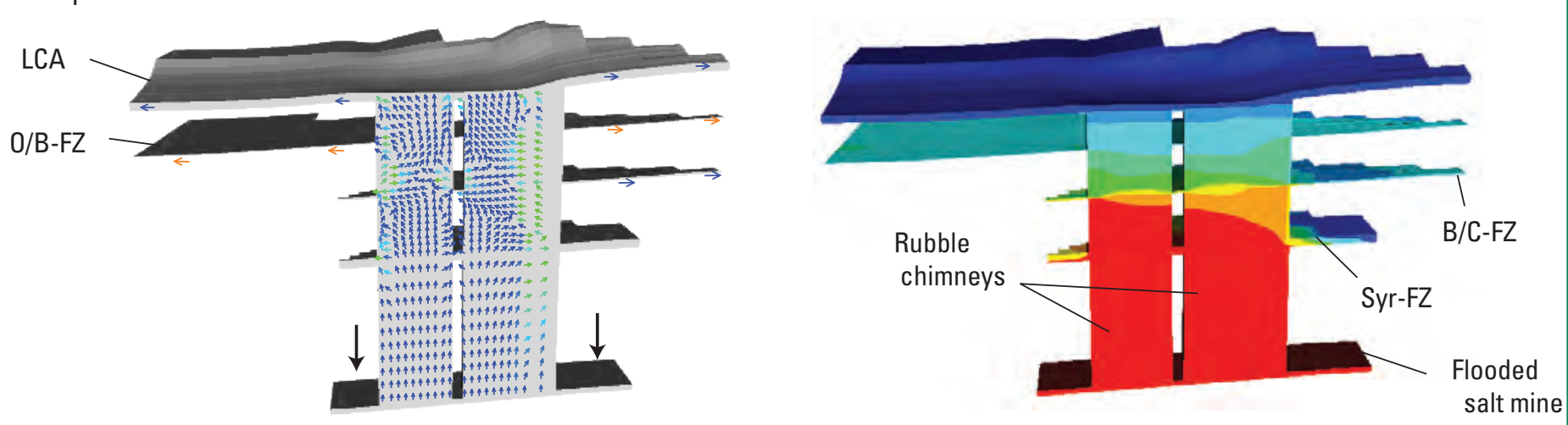

\section{EXPLANATION}

Closure of mine cavity displaces brine from flooded mine

\section{$\leftarrow$ Direction of groundwater flow \\ 10 Color of vector arrows indicates groundwater velocity, in feet per day}

0.1

\section{EXPLANATION}

Halite saturation, in percent

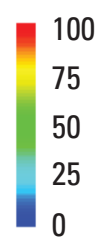

Figure 6. Examples of block diagrams along cross-section B-B' in collapse area showing results simulated by model $B$ for changing directions of groundwater flow (left) and changes in the spatial distribution of halite saturation (right) for $A$, January 1998 and $B$, September 2006. The simulation results indicate groundwater-flow exiting the rubble chimney to both the lower confined aquifer and the Bertie-Camillus fracture zone (B/C-FZ) from January 1998 to September 2006, and a reversal in groundwater-flow direction along the Onondaga-Bertie fracture zone (O/B-FZ), initially as an inflow, but then becoming an outflow. The halite saturation results indicate increased levels of halite saturation in the chimneys and intersecting fracture zones (for example, the Syracuse fracture zone (Syr-FZ)), as brine is displaced from the mine cavity and moves upward. Saline water was detected in the confined aquifer in 2002. Animations of model simulation results can be seen at http://ny.water.usgs.gov/projects/Coram/seawat/seawat.html. Location of section B-B' is shown in figure 5. From Yager and others, 2009, (fig. 20). 
A Section B-B'
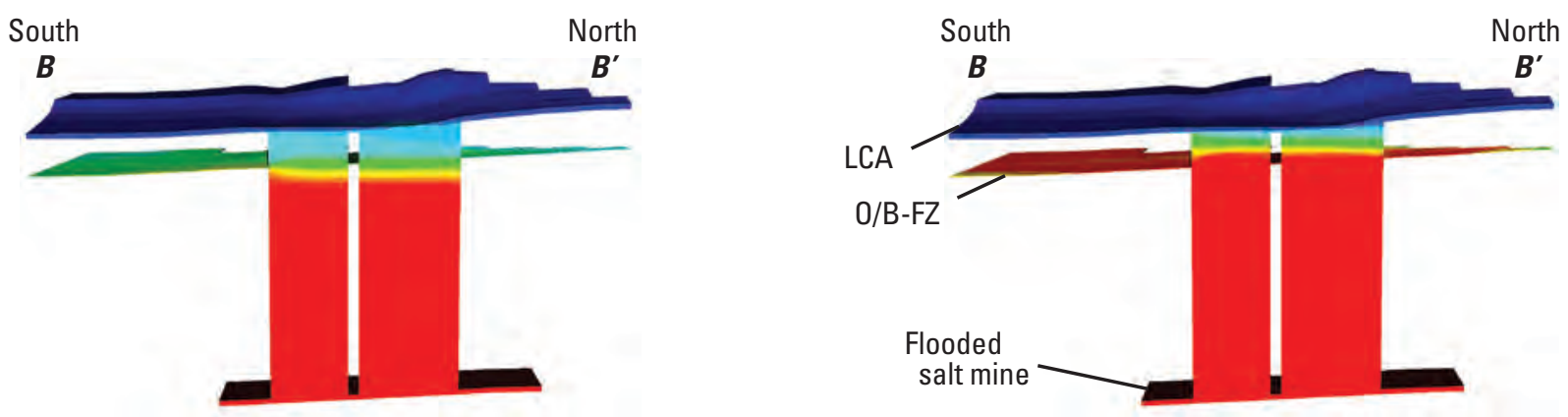

VERTICAL EXAGGERATION × 5

\section{B Plan view of O/B-FZ}
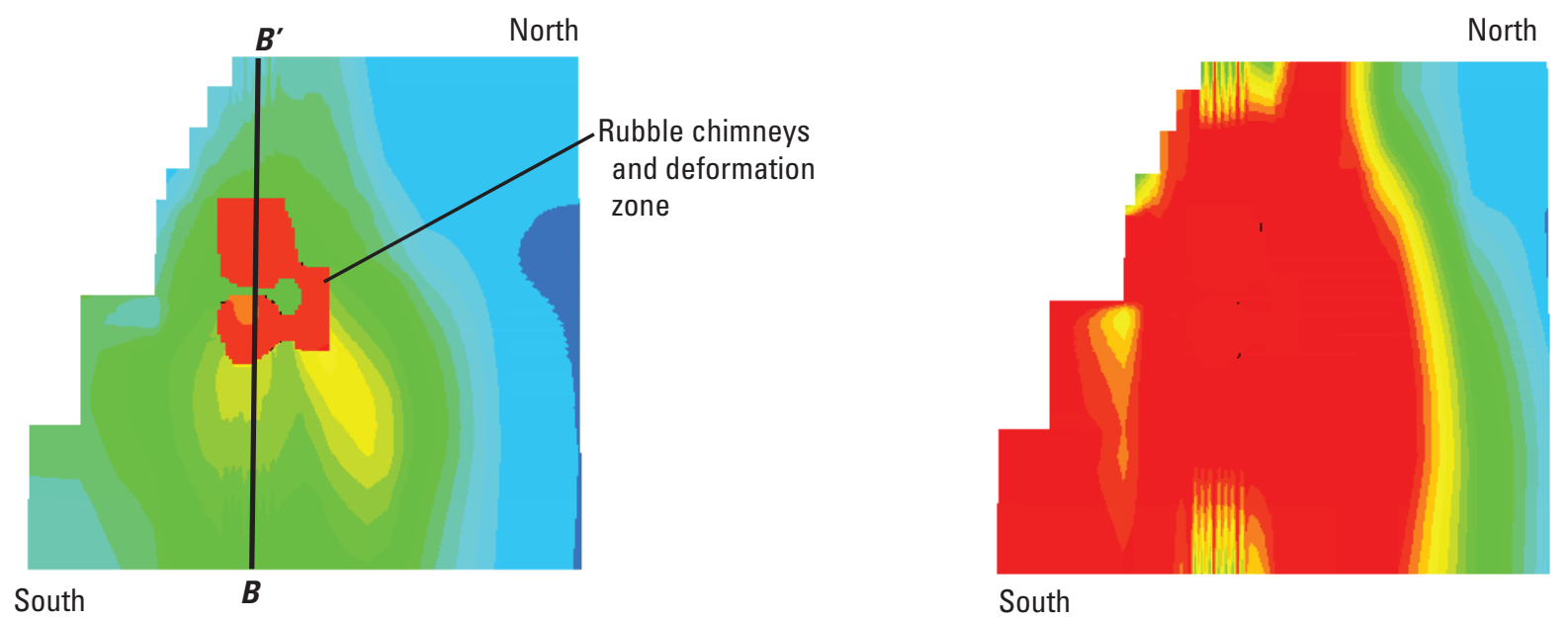

South

\section{Plan view of LCA}
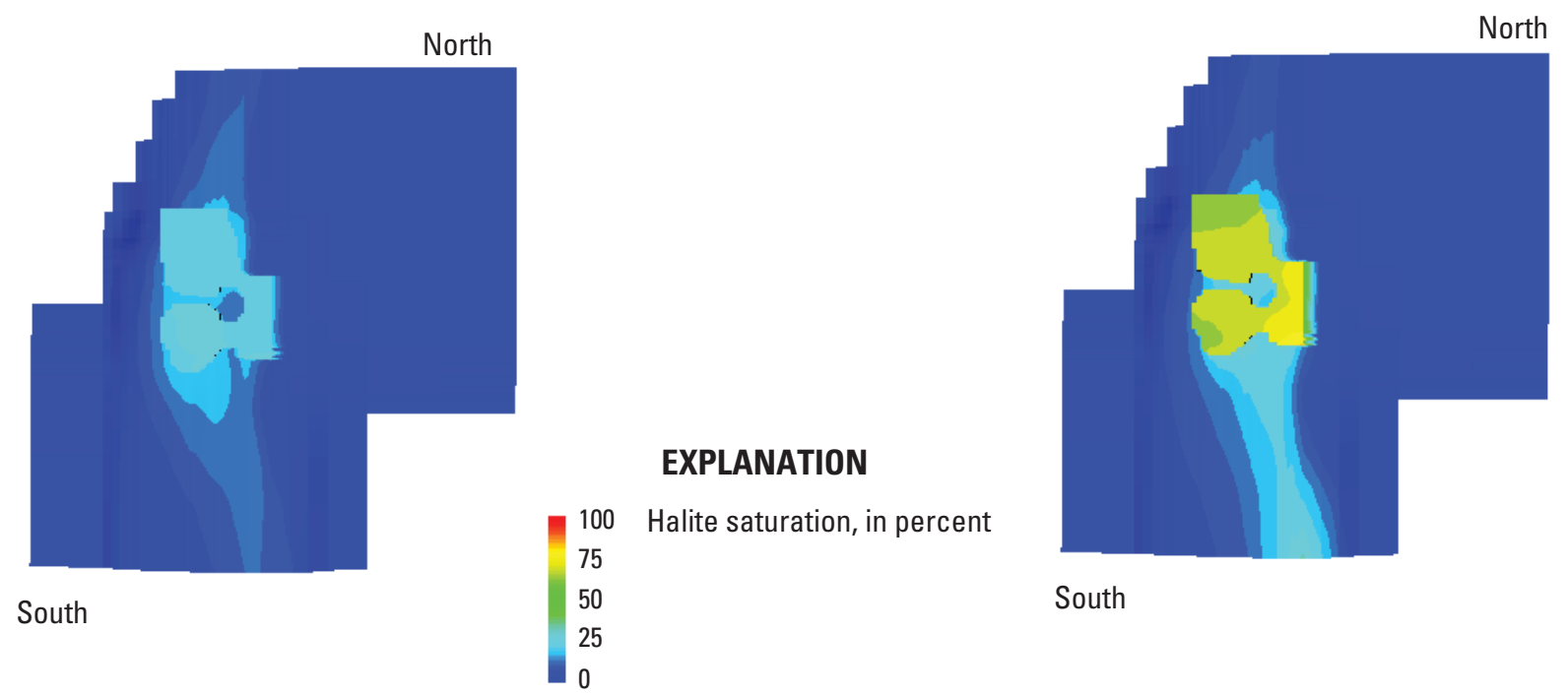

South

Figure 7. Simulated halite saturations in 2011 and 2016 following shutdown of brine-mitigation project after 2 years of pumping from September 2006 through August 2008: A, Along cross-section B-B' through the collapse area, the brine would rise nearly to the OnondagaBertie fracture zone (O/B-FZ) by September 2011 and spread throughout the zone by September 2016; $B$, plan view of the 0/B-FZ indicates that halite brine would fill the rubble chimneys and deformation zone by September 2011 and most of the modeled area of the zone by September 2016; and $C$, the plan view of the lower confined aquifer indicates that the halite saturation would increase to about 75 percent in the rubble chimneys and deformation zone by September 2016 and that a plume of saline water about 25 percent saturated would migrate southward along the sloping bedrock surface of the aquifer toward its lowest point, which is near Sonyea (figs. 1 and 2). 


\section{Selected References}

John T. Boyd Company, 1995, Impact analysis—Retsof Mine, Akzo Nobel Salt, Inc.: Pittsburgh, PA, John T. Boyd Company, 50 p.

Kelly, William, 2006, Geology and history of 1994 roof collapse of AKZO Salt Mine, Cuylersville, NY, in 2006 Interstate Technical Group on Abandoned Underground Mines Sixth Biennial Workshop, June 14-16, 2006, Rochester, New York, accessed April 23, 2011, at http://www.dot.ny.gov/conferences/itgaum.

Langevin, C.D., Thorne, D.T., Jr., Dausman, A.M., Sukop, M.C., and Guo, Weixing, 2007, SEAWAT version 4: A computer program for simulation of multi-species solute and heat transport: U.S. Geological Survey Techniques and Methods book 6, chap. A22, 39 p.

New York State Department of Environmental Conservation, 1997, Collapse and flooding of Akzo Nobel's Retsof salt mine, Livingston County, N.Y.: Albany, N.Y., Division of Mineral Resources, 113 p.

Parkhurst, D.L., and Appelo, C.A.J., 1999, User's guide to PHREEQC (version 2)—A computer program for speciation, batchreaction, one-dimensional transport, and inverse geochemical calculations: U.S. Geological Survey Water-Resources Investigations Report 99-4259, 310 p.

Yager, R.M., Miller, T.S., and Kappel, W.M., 2001, Simulated effects of 1994 salt-mine collapse on groundwater flow and land subsidence in a glacial aquifer system, Livingston County, New York: U.S. Geological Survey Professional Paper 1611, 85 p., at http://pubs.usgs.gov/pp/pp1611/.

Yager, R.M., Misut, P.E., Langevin, C.D., and Parkhurst, D.L., 2009, Brine migration from a flooded salt mine in the Genesee Valley, Livingston County, New York-Geochemical modeling and variable-density flow: U.S. Geological Survey Professional Paper 1767, 52 p., at http://pubs.usgs.gov/pp/pp1767/.

By Richard M. Yager, Todd S. Miller, William M. Kappel, Paul E. Misut, Christian D. Langevin, David L. Parkhurst, and M. Peter deVries

\section{Selected USGS Reports Related to Salt Production, Brine, and Saltwater Intrusion in New York}

»Salt - Statistics and Information (shown right) from USGS National Minerals Information Center, Mineral Commodity Summaries, January 2012 at http://minerals.usgs.gov/minerals/pubs/commodity/salt/.

» The Retsof Salt Mine Collapse-Widespread subsidence occurred after a mine collapse in the Genesee Valley, New York at http://pubs.usgs.gov/circ/circ1182/pdf/14Retsof.pdf.

»Salt production in Syracuse, New York ("The Salt City") and the Hydrogeology of the Onondaga Creek Valley at http://ny.water.usgs.gov/pubs/fs/fs13900/FS139-00.pdf.

» Halite brine in the Onondaga Trough near Syracuse, New York: Characterization and simulation of variable-density flow at http://pubs.usgs.gov/sir/2007/5058/.

»Chloride in groundwater and surface water in areas underlain by the glacial aquifer system, northern United States at http://pubs.usgs.gov/sir/2009/5086/.

»Evaluation of well logs for determining the presence of freshwater, saltwater, and gas above the Marcellus Shale in Chemung, Tioga, and Broome Counties, New York at http://pubs.usgs.gov/sir/2010/5224/.

» Simulation of variable-density ground-water flow and saltwater intrusion beneath Manhasset Neck, Nassau County, New York, 1905-2005 at http://pubs.usgs.gov/sir/2008/5166/.

\section{U.S. salt sold or used in 2011, by percent production type (total 44 million metric tons)}

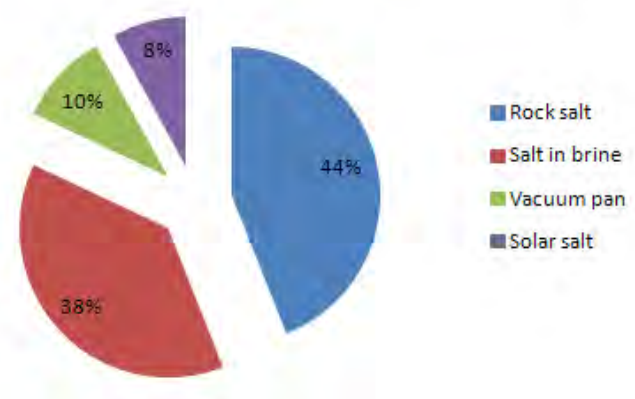

\section{U.S. salt use in 2011, by percent of \$1.7BY estimated total sales}

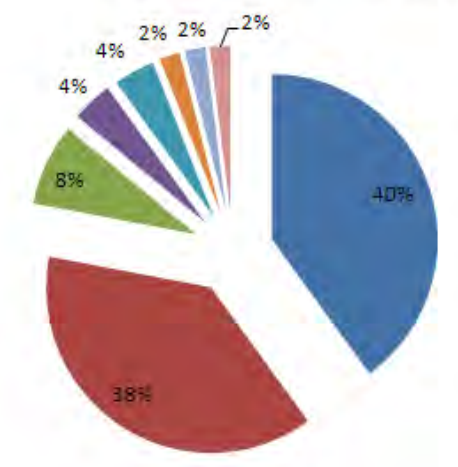

nemical industry

nighway Deicing

Distributors

agricultural

a food

anenal Industria

-Water Treatment

ather Exports 


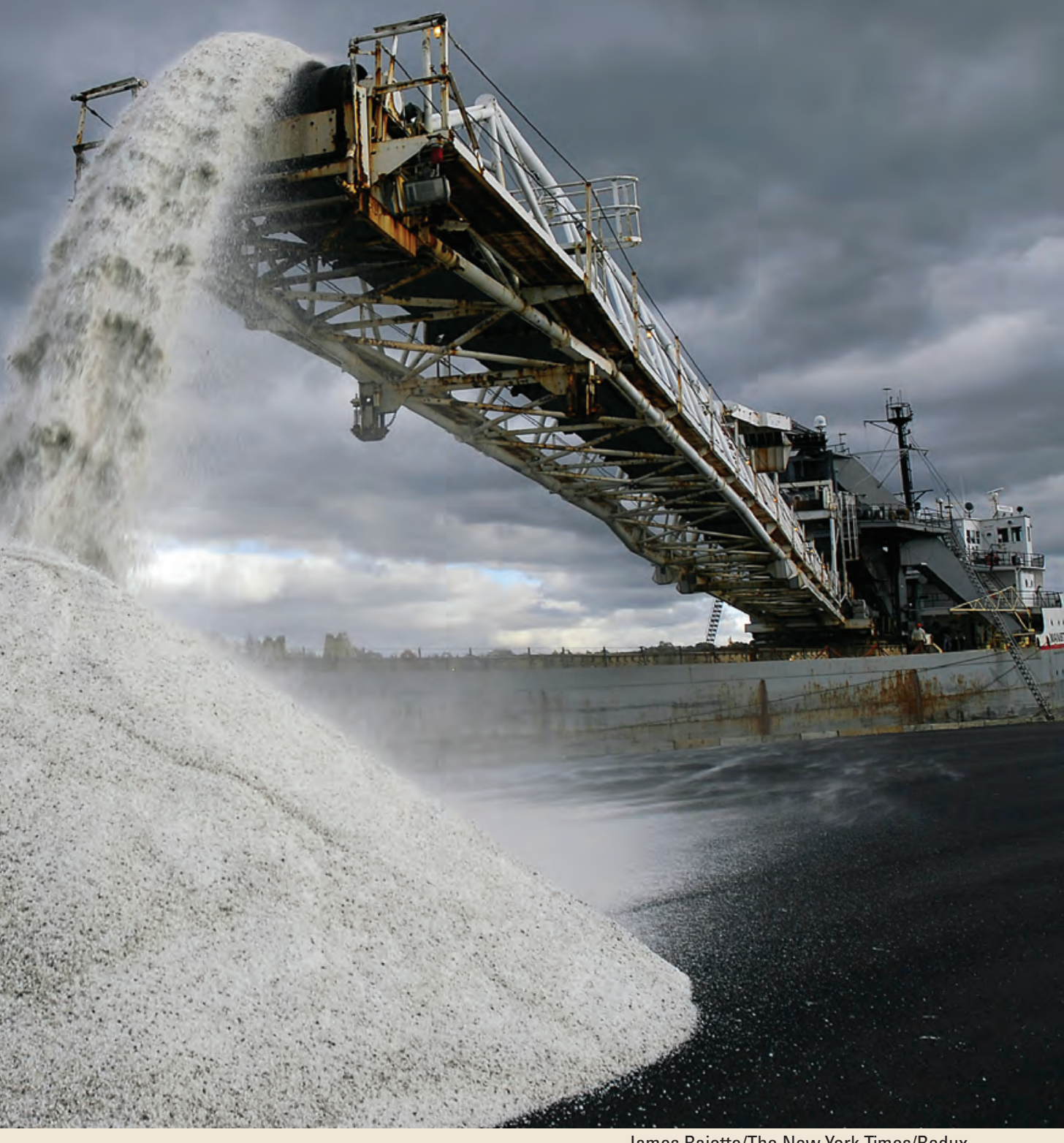

Rock salt being unloaded off of a ship in Oswego, New York, October 2007

James Rajotte/The New York Times/Redux

For more information, please contact:

New York Water Science Center

U.S. Geological Survey

30 Brown Road

Ithaca, New York 14850

Information request:

(518) 285-5602

or visit our Web site at:

http://ny.water.usgs.gov
For more information on the USGS - the Federal source for science about the Earth, its natural and living resources, natural hazards, and the environment, visit http://www.usgs.gov or call 1-888-ASK-USGS.

For an overview of USGS information products, including maps, imagery, and publications, visit http://www.usgs.gov/pubprod

Any use of trade, product, or firm names is for descriptive purposes only and does not imply endorsement by the U.S. Government. 